\title{
Chapter 1 Concha \& Amalias's Kaloskeagathos
}

\author{
Quien de admirarte no se torna cisne, \\ recoge en sí el más suave tacto, \\ temeroso ante el enigma, \\ al abordar las formas de esa triple ecua- \\ ción, \\ entre Keats y Platón entretejida? \\ Pues si en ti verdad y belleza son bondad \\ Su despojada esencia es tan humilde, \\ Que por sencilla y pura se hace altiva, \\ Más, !ay!, por entregada libre \\ $Y$ a la par cautiva. \\ Clara Janés, "Leda cautiva" (1983) ${ }^{1}$
}

Like any other Saturday, Amalia was looking forward to having lunch with her neighbor Concha. They had been friends since the late 1960s when they were both students at the University of Granada. Now they lived in adjoining apartments $C$ and $\mathrm{D}$, on Melchor Almagro Street by the Colegio de Ciencias.

Their lunches were ritualistic rather than routine, reflecting the reverence with which they treated their long friendship. Concha had lived alone for three years after suffering through a traumatic divorce. Amalia, still married and a mother of

Who from admiring you would not turn into a swam

gather within herself the softest touch

afraid of the enigma

posed by the contours of that triple equation

interwoven from Keats to Plato?

Because within you, truth and beauty are goodness

their generous essence so humble

that being so simple it is really lofty

but, Oh! so faithful and free

while at the same time enslaved.

Clara Janés, Vivir (Madrid: Hiperión, 1983), 55. [My translation intends to capture the meaning of this beautiful poem by Clara Janés.] 
two, extended her family in offering. Concha accepted and became one of Amalia's family.

Figure 1: Concha with Amalia's family watching TV after lunch for the last time (1990)

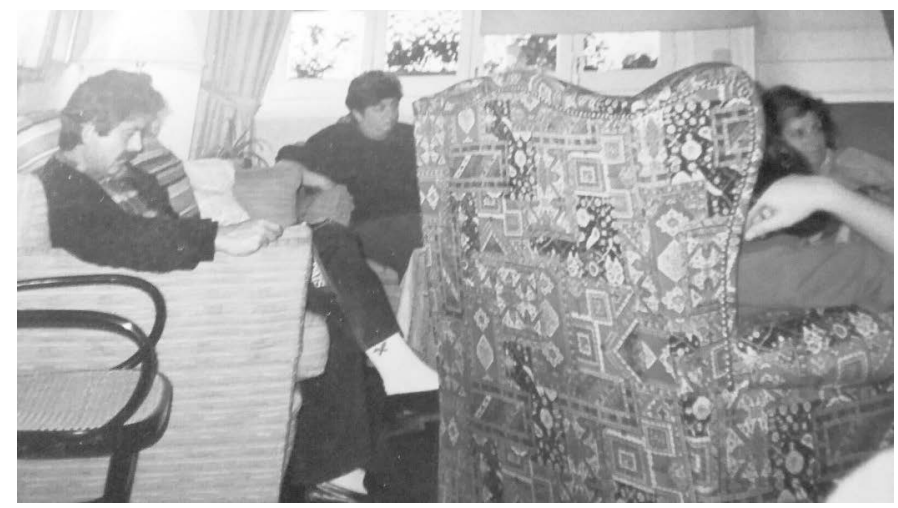

When Concha did not call that Saturday, Amalia was not particularly worried. She knew that Concha was making last-minute edits to her new book on renaissance art in Granada and assumed she had lost track of time. When she saw her the next day, Concha would tell her all about it. But that next time never came.

Work had always been Concha's safe harbor. It had sustained her after her infant daughter died suddenly. It nurtured her after her divorce. And now it kept her going when other areas of her life seemed to fail her. Instead of wearing her struggles on the outside, though, Concha kept them tucked away. On the surface she was all business, with a wry, some would say sardonic, sense of humor. Underneath, a sense of world-weariness occasionally seeped through.

Concha was an Associate Professor of Art History at the University of Granada. As well as being a noted Art Historian, she was well known in Granada's political circles-part of the clandestine student movement of the late 1960 s and later, during the transition, a proud candidate for the newly legalized Communist Party.

Despite her well-known public persona, Concha was an enigma for many. Coming from a background of privilege, she became an ardent Communist. Raised as a true believing Catholic, she shed her religious carapace without losing her Christian zeal to serve the less fortunate. She had risked everything-career, family, relationships-many times for her political beliefs, and would do it all again.

A year before the missed lunch date, I met Concha in her apartment, with Amalia joining us. It was May 3, 1989, the Day of the Cross. Outside, a multitude of carnation covered crosses-monumental, large, medium, and small-festooned 
every park and plaza. Manila shawls hung from balconies while children, looking like miniature adults in their colorful flamenco dress, paraded through the streets.

This year, I was not focused on the colorful celebrations but on my interview. I was leaving for the University of New Mexico (in the United States) in a few weeks, and I had to finish my research beforehand. As an overly earnest graduate student, lucky enough to come of age during the transition, I had the freedom to study abroad and to critically investigate what had been until recently a taboo topic-women under Franco. My fellow female students and I saw ourselves as a generation of change in the recently liberated Spain. Concha and Amalia were from the generation before mine. During their college years they did not enjoy the same freedoms. In fact, they had to fight a clandestine resistance that made my studies even possible. They were my spiritual godmothers.

Concha and Amalia had belonged to "Mujeres Universitarias" (University Women Association) established in 1976 at the University of Granada. ${ }^{2}$ The Association provided legal cover for women of different ideological backgrounds to press a liberal feminist agenda, before the political parties were given official approval. Catalan professor Montserrat Rubio Lois took the lead in establishing a chapter of the Association and was the president. Some of the executive board members included: Mari Luz Escribano Pueo and Concha Félez as vice-presidents and Julia García Leal, Carmen Guerrero Villalba, and Angela Olalla Real. In the beginning the Association formed several committees: urban planning, education and teaching, women's legal counsel, and health. An important focus was on the struggle against discrimination of women within academia. Another was the increase in tuition that was a hardship for working class women. The Association also fought for daycare at the university, access to birth control, the legalization of divorce, and the need to reform the still extant Francoist civil and penal codes that discriminated against women. In addition, the Association focused on urban and cultural reform. Creating welcoming public spaces for women was considered important in the feminist agenda, as was promoting a more inclusive cultural and artistic agenda that went beyond the religious laden, anachronistic one imposed by Franco's regime. The University Women supported a $40^{\text {th }}$ anniversary tribute in honor of poet Federico García Lorca, a symbol of anti-fascist sentiment who

Founded in Oviedo and Madrid in 1953, the Asociación de Mujeres Universitarias replaced the former Asociación Española de Mujeres Universitarias, founded by Clara Campoamor and María de Maeztu during the Second Republic (1931-1936) with members such as Soledad Ortega Spottorno, daughter of philosopher José Ortega y Gasset, and the Granadina Isabel García Lorca, sister of poet Federico García Lorca. The 1930 s association soon had a presence all over the country and joined the International Federation of University Women, founded after World War I with the mission to improve women's access to higher education. The Spanish Civil War (1936-1939) meant the end to their activism, understood in feminist terms until 1953, when the new Asociación de Mujeres Universitarias was established. 
was assassinated by the regime in August 1936 in Fuente Vaqueros, just outside Granada. They fought to rename streets honoring Franco-era stalwarts, and to preserve the stately trees lining the then named Boulevard Calvo Sotelo (named after a fascist MP assassinated in Madrid before the Spanish Civil War). The crowning glory of their many achievements, though, was uncovering a plot in 1977 to turn the historic Carmen de los Mártires into a private hotel.

The three of us sat in plush armchairs around a coffee table in a small living room lined with bookcases full of Concha's art books. As Carmen spoke, a cloud of cigarette smoke hung over her head, punctuating her sardonic speech like a diaphanous diacritical mark.

Concha remembered the profound emotional blow she felt when she moved to Granada: "I cried for three months. Granada was very different from Málaga where I was born, and from Madrid where I grew up in the bourgeois Barrio de Salamanca." At that time, in the early 1950s, Madrid projected a cosmopolitan air, while Granada held fast to its provincialism. In Madrid, Concha attended the Colegio de la Asunción on Velázquez Street, an elite nunnery school that sent most of its girls to college. That was not the case in the high schools of Granada, where the daughters of the bourgeois had to fight to be able to attend college. "There existed a great isolation in Granada... You need to take into consideration that this was a closed city both geographically and historically. I was invited by a Señorita Granadina to spend the day in her country home. I made sure to dress very prim and proper. Her brother drove me back to my dorm afterword and remarked, 'I am so pleased to have met you, because, although you are from Málaga and a college girl, you are still very nice and proper.' I was so offended. What did he expect, that I was going to eat the soup with my fingers? You, Amalia, deserve a lot of credit coming from this town...."

"Perhaps because in my family," reflected Amalia, "we never went without but did not have extra either. We were seven brothers and sisters, and I was the oldest girl. This meant that my mother relied on my help, and my studies were always secondary. Nobody seemed to understand that I needed time to read and study for exams. It was a constant battle. I went to the Regina Mundi nunnery school run by the Daughters of Charity," Amalia said with ironic emphasis on the word "charity." "I saw so much prejudice in that school against the so-called 'gratuitous' girls, in comparison to ones like me whose families could pay tuition," she recalled. "While we entered through one door, in our wool uniforms with starched white collars, the 'gratuitous' girls had to come in through a separate door in the basement where they were sequestered and taught. We were not allowed to mix."

This blatant discrimination made a big impression on Amalia that carried over into her later years. "I would have preferred attending the public Ganivet Institute, but my parents refused to even listen to my pleading. My mother thought that the girls from the public schools were not, in her words, properly protected. This from 
a woman who was not particularly right wing. That was a difficult time for me and had a profound impact on my life."

Concha was forced to compromise as well over the course of her studies. "I had wanted to study law but there was little professional future for women in the field, until the law of Political and Professional Rights for Women was approved in 1961, one year after I began college. I decided to continue in Philosophy and Letters rather than start over."

From 1961 to 1965 Concha lived in the Residence Hall of Jesús María where she enjoyed a rich extracurricular life of tertulias, poetry readings, and theater. This was a time of transformation for the university. Beside a richer cultural life on campus, the out-of-town students were allowed to rent private flats, fostering even more independence and autonomy.

"I was so jealous of the out-of-town girls," Amalia remarked. "I missed out on so many college experiences because I lived under the control of my family. This was a big difference between us, the local students, and those from outside Granada."

Concha acknowledged her friend's frustration and added, "In the dormitories you met people from different backgrounds and parts of Spain. There was an excitement being away from home for the first time as women and having some of the freedoms that only men used to have. It wasn't just the freedom to come and go as we pleased, but to think for ourselves as women and imagine a different future. And it wasn't just an island of women. Our Residence was located across from the male Loyola Residence, and both dorms organized co-ed activities. This is where I met some of the future politicians of the democratic transition. I lived in the dorms eight years, first as a student and then as an instructor, until I married in 1969."

"One of the most frustrating things of my college years," Amalia lamented, "was the lack of autonomy and access to all the things Concha is describing.... I did not even have my own room at home.... Those College Dorms were a separate world, physically and culturally. I studied classical philology, Greek and Latin, and immediately after graduation got a job in Málaga. I couldn't wait to leave home...."

"You had so much fun," Concha muttered. "You got a boyfriend right away." Amalia ignored the last comment and continued reminiscing: "I remember fondly going to the movies. That was so much fun...cinema, cinema, cinema. Reading film magazines like Fotograma or Cahiers du Cinema. The wonderful films of Antonioni or Truffaut."

"I could not stand the French ones... the American comedy was fabulously light-" interjected Concha. "You know, my husband, Juan Carlos, had not met me yet, and he used to tell the story that one day while visiting the dorm he had heard me entering the lobby yelling, 'Girls, I just saw a fabulous movie! Scaramouche!' He always remembered that anecdote warmly" - Concha sounded nostalgic, longing-"because, you see, he had enjoyed it too and was pleased to hear me say I had 
liked a popular film.... He would say, 'Wow! I could not believe it, because you had a reputation for being very studious."

Admitting any kind of frivolity was not something university girls could afford to do. They had to prove they were bona fide intellectuals, fully committed to their studies.

"Panties-ville, remember?" said Concha, looking at Amalia. "That's how the guys used to refer to our Philosophy and Letters College."

"Yes, of course, because our college was almost all women. It was even more obvious once we moved from Puentezuelas in the city center to the Cartuja campus on the outskirts of town."

"It was also a way to put the agitators outside of the urban center where the police could easily contain us," Concha pointed out.

"By that time the Women's Section girls (the state sanctioned women's group) were losing popularity," continued Amalia. "They cultivated a very austere style."

"Remember those cheap uniforms? ...blue blouses and grey skirt suits. Their demeanor was kind of mannish," said Concha.

"Yes, I thought they looked a little butch," murmured Amalia.

"We called them marimachos (tomboys, butch)," added Concha. "You would never see them wearing makeup or flowery dresses. By the 1950s and 1960 s they were mostly from lower middle-class families, in contrast to the aristocratic elite that founded the Women's Section with Pilar Primo de Rivera and her university friends earlier in the regime. The Women's Section was often the only way they could afford to go to college."

"There were also the religious organizations. Concha, you were very active in the Congregaciones Marianas, ${ }^{4}$ right?" asked Amalia.

"Yes," Concha replied. "I had been a Daughter of María in school and continued my commitment to the Congregation in college until I joined the Communist Party. My family was very religious." After admitting this, Concha paused for a moment,

3 In the summer of 1936, shortly before the civil war erupted, the University of Granada announced that due to lack of space its goal was to move its facilities to the environs of the monastery of Cartuja in the northern part of the city. The war, and later the reluctance of the faculty to move away from the urban center, made the process extremely slow. Closer to the center of town was the area called Fuentenueva, where in 1962 the Faculty of Sciences, designed by Cruz López Müller, was built. The Philosophy and Letters building, inaugurated in 1976-77, was a 1971 design of Francisco Prieto-Moreno Pardo in the period's brutalist architectonic style: massive concrete structure on pillars, floor to ceiling windows.

4 Established in Rome in 1563, the Marian Congregations arrived in Spain in 1586 while female congregations were founded in 1751 . By the end of the $19^{\text {th }}$ the century, the Marian movement reached beyond the Jesuits' schools: the Daughters of María had significant membership, along with the male congregations for secondary education students called the Kostkas, and the university associations known as Luises. 
as if in reflection. She then began talking about her family's religious devotion. "My father used to collaborate with Málaga's noted bishop Angel Herrera Oria, ...I remember as a little girl going with him to the countryside where he helped build schools for the poor. My mother also was pious, but in a different way. Going to mass every Sunday was an unavoidable family ritual.... For me, actually, it was the most natural thing to do.... Sundays we went to mass and afterwards had cakes...you know, you picked up some cakes to take home... Therefore, at a very early age I joined the Congregaciones Mariana as the most natural thing for a girl from a respectable conservative family. I carried my father's religious commitment into my college years. These university religious groups paradoxically became seedbeds of leftist politics because our pledge to fix social problems sprang from our profound Catholic beliefs. We read the journals of the Christian organizations such as the French La Croix or Concilium...where you learned about not just the divine but also the human condition....all those thinkers and theologians that today remain a problematic crowd for John Paul II. Within the Congregaciones Mariana there were two positions; those who thought the purpose was to organize rosaries and communal prayers to the Virgin, and others, like myself, who spent our free time trying to solve the problems of poor gypsies in the Sacromonte. We wanted to transform the world. In that space and frame of mind, a leftist Christian discourse emerged, which led naturally to Marxist activism. For us, a commitment to social change was a mix of existentialism and Vatican II ecumenical principles. We were known as Federación de Congregacionaes Universitarias Marianas (FECUM, Spanish Federation of University Marian Congregations)." 6

"All that came about," interrupted Amalia, "because 1968-1969 was a year of division, of rupture, of separations. For me it was a significant moment because I was graduating and starting a job, taking off. It meant emancipation from my family. To be able to do whatever I pleased, read whatever I wanted, carve my own space...everything I had never enjoyed at home. I had not experienced any privacy at home and therefore my story is different from that of Concha...that is a big difference between us. The first year after graduating I got a teaching position in Málaga. As

5 Ángel Herrera Oria (Santander, 1886-Madrid, 1968) founder of, along with the priest Ángel Ayala, the Association of National Catholic Propagandist (ACNP) in 1910 and a year later launched the Editorial Católica with the daily paper El Debate. In 1936, just before the beginning of the civil war, he moved to Switzerland and entered the San Carlos Seminary and was ordained in 1940. Herrera Oria returned to Spain in 1943 to manage the parish of Saint Lucia in Santander. Through the ACNP he collaborated closely with the Francoist regime, becoming a broker in the discussions between the Holy See and the regime. In October 1947, he was appointed bishop of Málaga where he worked for a social Catholic program inspired by Leo XIII doctrine. He created over 200 hundred schools and led a literacy campaign.

6 Javier Alberdi Alonso S] and Juan Luis Pintos S], Actitud religiosa del universitario español: Encuesta FECUM 1967 (Madrid: Editorial Razón y Fe S.A., 1967). 
I was commuting back and forth, the PCE used me as a messenger to bring party documents between the two cities."

Amalia spoke with pride when she talked about becoming an agent for the PCE. She would not officially join the party until 1975 but was sympathetic to its aim long before. She readily agreed to ferry parcels back and forth between Málaga and Granada. She explained the routine, the repetition, the rhythm that filled her first year of emancipation: "I traveled by bus every Monday from Granada to Málaga and returned every Saturday afternoon. Someone would give me a package, wrapped in brown paper, and tied with thin twine. They did not tell me about the contents, and I did not ask questions. There was always someone waiting at the bus station who would take the package from me. I never saw the same person, and I never knew how they identified me. At the time this felt like a small transgression. Now I realize how dangerous it all was."

"Well...yes, of course, for you it was a complete departure," admitted Concha after listening to Amalia's rendition of those events. Concha then explained: "Really, for me the last couple of years of college were all about destroying the SEU. ${ }^{7}$ When I graduated in 1965, I was still a member of FECUM and later on...it must have been 1974...I spearheaded Mujeres Universitarias because we felt we had to organize ourselves for action. It was a global political approach, which meant the creation of a platform where women could have a visible impact in society and current affairs.... We organized working committees and were part of a national network linked to the Institución Libre de Enseñanza (Free Institution of Learning)."8

"We were criticized by several women's groups from the left because they found us to be too elitist," Amalia pointed out.

"We created this platform when there were no sanctioned political parties," continued Concha, "and it was precisely when the political parties started organizing

SEU (Sindicato Español Universitario), established in 1939 and dissolved in 1965, was the only state-sponsored student organization and part of the Falange. All students were mandated to join this organization, which served as a political means of control and socialization of the college youth. See Miguel Ángel Ruiz Carnicer, El Sindicato Español Universitario (SEU) 19391965: La socialización política de la juventud universitaria en el franquismo (Madrid: Siglo XXI, 1996).

8 ILE (Institución Libre de Enzeñanza) was established in 1876, based on the ideas of obscure Cerman philosopher Frederick Krause. It aspired to academic freedom and lay instruction, with one of its most important elements being the commitment to co-education of the sexes. Founded by Julián Sanz del Río, along with a small circle of Madrid University professors, it had a profound impact on Spanish politics and the educational system during the Second Republic (1931-1936). The Francoist regime committed itself to the eradication of all educational principles espoused by the ILE, declaring them to be anti-Catholic and thus, by definition, anti-Spanish. 
themselves for the first democratic elections in 1979 that our initiative dissolved. Most of us in the leading roles belonged to the Communist Party."

The Communist Party had been deeply entrenched among the student movement with an extensive clandestine network able to lead the anti-Francoist resistance rather than the almost nonexistent PSOE (Partido Socialista Obrero Español). ${ }^{9}$

"With Mujeres Universitarias our goal was to have an impact at the cultural and intellectual level because that was our setting, our place of action. That was where we were and where we spent most of our time," explained Concha. "One of the most relevant actions that we undertook concerned the Carmen de Los Mártires, ${ }^{10}$ which turned into a national scandal." The town hall closed down the historic site to begin construction of a hotel. The Carmen, a nineteenth-century palace and gardens built next to the iconic Alhambra, had long been a part of Granada's history.

"The site was very special for all Granadinos...we used to go there almost every day...to enjoy the sunny afternoons, to study...and...without warning the authorities closed it down," remarked Amalia.

"We broke into the property with two Dobermans that belonged to a wonderful woman, Mari Luz, ...remember her?" asked Concha. "A journalist married to one of the Marins, a very important family in town.... Well, she came with her dogs. The Alhambra Board of Trustees was involved in everything, you know. Scandalous. And even my boss, Dr. Pita Andrade, head of the Art History department at the University of Granada, was involved. We organized a series of lectures with slides to show the public the horrible destruction going on at the site. We received a downpouring of attacks...calling us leftist radicals etc., ...but it was a bombshell! We uncovered a real estate speculation scandal in which the Town Hall and the Alhambra Board of Trustees were deeply entangled."

"Now, there it is! We preserved Los Mártires," asserted Amalia proudly.

The Socialist Workers Party (PSOE) was founded in 1889 by Pablo Iglesias. They also had a trade union UGT (Unión Ceneral de Trabajadores). For more information, visit http://www.fp abloiglesias.es/.

10 Carmen is the name of a typical Granadina estate house. The name derives from the Roman term "Karmen," meaning vines, which were commonly used in the gardens of these houses. The Carmen de los Mártires sits on a hill in the proximity of the Alhambra overlooking the fertile valley countryside and Sierra Nevada, as well as a Moorish castle. A Carmen follows a topographical design in several levels that expands from the interior of the house to the surrounding lavish gardens. The Carmen de los Mártires was built on a site that was previously occupied by a Franciscan monastery until the disentitlement process that led to Ceneral don Carlos Calderón's purchase in 1845. In 1957, Granada's Town Hall purchased the property, and in 1972 the city opened a public contest to demolish the Carmen and build in its place a hotel. It is during this time that Mujeres Universitarias engaged in a campaign to save the estate. For more on this monument see: http://www.granada.org/inet/palacios.nsf/xedbynombre/58 475794CDC857ECC1257188003A3DAo. 
These women claimed the right to the city space for the people of Granada. The Carmen de los Mártires remains today a valuable historical site and beloved public space where couples celebrate civil marriages, families stroll through the gardens, and elderly couples sit in the sun. Concha and Amalia never thought they were waging a feminist fight, but simply a fight for justice. This simple ideal captured so much about what the determined band of university women fought for. When women win, everyone wins.

Ultimately what drove both Concha and Amalia was a struggle for their own autonomy. They were tired of having to ask permission from men, or even from women's organizations controlled by men. They wanted to make their own decisions, not only as individuals, but as part of a larger collective who shared their history of oppression and their longing for a more equitable Spain. At the heart of this struggle was the economic discrimination that women had for so long been the target.

"Our generation was very clear on what was our main objective from a feminist perspective, and that was economic independence...everything else was secondary," stated Concha.

"Well...yes, that is a feminist issue obviously, but I am not sure we were aware of it or even called it feminism at that time...were you?" asked Amalia.

"Yes, yes, yes I am convinced," affirmed Concha.

"I am not!" declared Amalia.

"I am, I am convinced," emphatically asserted Concha. "Because, as I have told you many times...my parents had a very conventional marriage and yet, since I was a little girl, I hated when my mother had to ask my father for money...I don't know...I saw her every October beg my father: 'Andrés, I have run out of money this month because I had to buy winter shoes for them," Concha enacted her mother's voice with visible indignation. "That was something that made my skin crawl.... And I remember I used to tell myself...this is a society for both men and women...I saw it from a very young age...I knew that situation was utter stupidity, and I was determined not to follow that path."

"We were feminist without knowing it," concluded Amalia.

"In my case, I had been raised like a boy," continued Concha heatedly, "with all the perks and possibilities, and then I saw the contradiction so clearly.... So, I was like a boy until I turned twenty and then I had to explain myself to a man so he would give me a thousand pesetas...? Oh no, never...that does not make any sense whatsoever!"

The context of the university also offered a different set of challenges when it came to their relationships with male colleagues. As students, intellectually, they often were superior to their male counterparts, performing better on examinations and receiving higher grades. But this did not translate into more opportunities 
once they graduated. Concha did get hired as an instructor at the University of Granada but was denied promotion to full professor.

"When they denied me the promotion to full professor, one male colleague told me, 'Well, Concha, don't worry, you are married anyway...'. When referring to a male candidate competing with you, they would say something like, 'See, you need to understand that he has a family...' and then when I separated from my husband they would tell me, 'obviously you don't feel like competing again for promotion, right? You must be so upset....' Nobody would say anything like that to a man!" Concha continued with indignation. "This was already the late 1970s and the early 1980s.... So, sexism might not be as blatant at first sight, but shows up as soon as you try to step outside of the conventional space assigned to you.... I wanted to punch them," remarked Concha, laughing. "I decided not to put myself through any more of those grueling promotion committees.... Why should I become a full professor, anyway?"

We concluded the interview that day with high spirits. I left shortly after for the University of New Mexico where I had been awarded a doctoral student assistantship. My dissertation topic morphed into studying the official Catholic discourses of the regime (the basis for my first book, True Catholic Women), and the interviews I had made shortly before my departure languished in their plastic cassette cases until thirty years later, when I awoke them from their slumber. After listening to them, I decided it was time to catch up with my old friends. We had lost touch after I left for the United States. My research had gone in different directions, and I had not taken up the topic of university women again. I was no longer a wide-eyed graduate student interviewing my heroes, but a battle tested senior scholar with my own past to deconstruct. Amalia was only a phone call away. One morning, sitting in my office in Florida, I decided to make the call and transport myself back to that afternoon thirty years ago.

Amalia is a grandmother now. She retired as soon as she turned sixty and is enjoying her new role as matriarch. I reminded her of what we discussed so long ago and took up the conversation as if it were yesterday. I asked her to elaborate on what was said. On April 14, 1977, she was arrested along with fifteen other university professors for putting up posters on the streets demanding the legalization of all left-wing political parties, including the PCE. While they were plastering posters on the walls in the San Agustín Public Market in the downtown area, a strange man wearing a trench coat pulled a gun on them and led them to the Plaza de los Lobos police precinct. "I was terrified because I thought this was a fascist fanatic ready to shoot us," Amalia recalled. "Once we reached the police station, I felt we might be alright." 
The undercover policeman had taken it upon himself to catch some Communists, even though the party was on the verge of being legalized. Amalia spent the night in jail and had to go before a judge the next morning in the sixteenth-century building, The Chancillería. She remembered how the authorities were not sure what to do with them. It was Holy Week, and by Sábado de Gloria, in three days, the government would legalize the PCE. "When we left the courthouse and came out into Plaza Nueva," Amalia smiled, "a large crowd was there hailing our bravery, throwing carnations and making us feel like heroes."

Amalia is proud of her activism in the PCE, which she believes was the result of her Catholic upbringing. For her, Christian values were her moral compass: "Nothing to do with the institutional Catholic Church that was always on the side of the powerful rather than coming to the aid of the poor. Therefore, the PCE provided the means to put into action those moral values they had inculcated us with in nunnery school. The Party," she remembered, "reminded us to be always coherent with our principles and preserve our integrity. If we wanted to truly change society's injustices, we had to be exemplary in our conduct everywhere we went: in the workplace, our home, our studies. So, my work has always been for me a very serious facet of my life and self-esteem. I was never interested in parliamentary appointments or the big political game but rather in being the best Communist, the best person I could be in my immediate circle. That's why I left the party as soon as I saw the internal power struggles and backstabbing. This resonated with me as a classicist, and I highlight it to my students when discussing ancient Greek and Roman culture. During Homeric times the oral tradition promoted the notion of Kaloskeagathós for the hero, the perfect fusion of beauty and goodness. As Plato would further elaborate, goodness is always beautiful. I am not talking about a physical beauty. Goodness and beauty are inseparable qualities and perfectly squared with my Christian upbringing. Therefore, the best Communist person must necessarily be the best worker, the best friend, the best human being." Amalia was quiet for a moment and then with tears in her eyes, said, "That was Concha. She was an extraordinary human being, 'bellísima persona."

She takes me back to that Saturday in the spring of 1991 when she did not know why Concha had not shown up for lunch. "On Friday we dined at my place, and I was looking forward to seeing her the following day. By night, I became really worried. She had not answered the phone all day. When I went to the balcony that separated both of our apartments and saw the lights and her television on, my heart sank. I opened her door with the spare key I kept and went in. There I found her on her bathroom floor, dead. The clothes she was wearing the day before for dinner were on top of the bed. She had had a massive heart attack." Amalia is silent. "This is the first time in many years," she uttered, "that I have spoken of this day." Amalia lost her Kalóskeagathós friend when Concha died in 1991. 
After the legalization of the PCE, Concha ran for office on the Party's ballot to be an MP in the general election in June 1977. She was the only woman who participated in the first PCE rally in Granada on April 20, speaking alongside General Secretary Santiago Carrillo, among other local male comrades. Between 1978 and 1981, Concha was one of six women who were part of the PCE's Provincial Committee (a total of forty-four members) and a delegate of the PCE First Regional Congress in 1979. Her name appeared on a list of 3,000 Spaniards (fifty-one from Granada, seven of them women) who probably would have been jailed-if not shot-if the February 23, 1981, coup d'état had been successful. ${ }^{11}$

Amalia remembers Concha's heroism. She remembers how difficult it had been for Concha to overcome the shunning of her conservative family. The day she was to speak at the rally with Santiago Carrillo on April 20, 1977, she had a fainting spell as a result of a fight with her sister, eleven years older than her and a member of the ultra-conservative Opus Dei. Amalia was standing by Concha as she engaged in a heated conversation over the phone. No sooner had Concha hung up, she passed out. Amalia and her husband picked Concha up from the floor and helped her regain her bearings. They were running late to the rally. "She was so strong," Amalia remarked. "Her speech was inspiring that day, and after the rally we went to celebrate over a beer at a local bar. She then confided in me what had happened. She had received a call from her sister because in a week's time Concha's goddaughter would make her First Communion. This was their brother's little daughter, Vanesa, who Concha called 'mi Vane." Her sister was furious because Concha was running for office with the Communists. She told her that the family was ashamed of her and that she was not welcome at the First Communion in Málaga. Amalia remembers how Concha started sobbing as she retold the episode in the dark corner of the small, packed tavern.

Concha remained committed to social justice her entire life. She was also a paradox-a privileged woman professing such a fervent belief in communism. She unselfconsciously used to wear her mink coat to distribute the Communist newspaper in the main street in town, La Gran Vía. Amalia tried to explain: "She was a cultivated person, very educated, who realized how the true great minds in our history always sought to make the world a better place." Amalia continued, "She believed in the Christian principles of justice, just not in the Church itself. We saw the PCE as the best means of action at that particular moment in time."

The religious upbringing of the two women ironically radicalized them. The blatant unfairness of the regime toward women was clear to everyone, but it took the clandestine student organizations to turn resentment into action. The feminists 
were a natural fit with the Communists. Both groups were seeking to break out of the Francoist straight jacket and saw each other as natural allies. The experience in clandestine politics helped turn the radicals of Franco's final years, like Concha and Amalia, into savvy politicians during the transition. Their life-long friendship was a testament to the strength of those bonds and the lasting effect they had on creating a better place for women in a modern Spain. 